\title{
EVALUASI TERAPI OBAT ANTIPLATELET PADA PENGOBATAN PASIEN STROKE DI INSTALASI RAWAT INAP RSUD AM PARIKESIT TENGGARONG PERIODE TAHUN 2014
}

\author{
Muhammad Hafidz Assaufi*1, Mirhansyah Ardana', Muhammad Amir M.² \\ ${ }^{1}$ Fakultas Farmasi Universitas Mulawarman, Samarinda \\ ${ }^{2}$ Fakultas Keguruan dan Ilmu Pengetahuan Universitas Mulawarman, Samarinda \\ *email :hassaufi@gmail.com
}

\begin{abstract}
ABSTRAK
Antiplatelet memiliki peranan penting dalam pengobatan stroke, pemberiaan antiplatelet bekerja dengan cara mengurangi agregasi platelet sehingga dapat menghambat pembentukan trombus pada sirkulasi arteri. Penelitian ini bertujuan untuk mengetahui tingkat ketepatan penggunaan antiplatelet pada pasien stroke di Instalasi Rawat Inap RSUD AM PARIKESIT berdasarkan pedoman antiplatelet Canadian Cardiovascular Society Guideline tahun 2011, dan PERDOSSI yang meliputi tepat indikasi, tepat pasien, tepat obat, dan tepat dosis. Penelitian ini menggunakan rancangan penelitian non eksperimental (deskriptif). Pengumpulan data dilakukan secara retrospektif yaitu data dari catatan rekam medik pasien. Subjek penelitian adalah pasien yang memenuhi kriteria inklusi diagnosis utama stroke mulai dari awal sampai akhir perawatan baik yang mendapatkan terapi antiplatelet maupun yang tidak mendapatkan terapi antiplatelet selama perawatan. Data yang diperoleh kemudian diolah dengan analisis deskriptif. Hasil penilitian ini pola pengobatan penyakit stroke yaitu antiplatelet tunggal yang digunakan adalah Aspirin (48,6\%), cilostazol (25\%) dan clopidogrel $(11,1 \%)$. Antiplatelet kombinasi yang digunakan adalah aspirin + clopidogrel $(2,7 \%)$, cilostazol + clopidogrel $(11,1 \%)$ dan aspirin + cilostazol $(1,3 \%)$. Hasil analisis ketepatan penggunaan antiplatelet adalah tepat indikasi adalah $100 \%$, tepat pasien adalah $100 \%$, tepat obat adalah $87,5 \%$, tepat dosis adalah $90,2 \%$.
\end{abstract}

Kata Kunci : antiplatelet, instalasi rawat inap RSUD AM Parikesit, ketepatan pengobatan, stroke

\begin{abstract}
Antiplatelet have an important role in the treatment of stroke, antiplatelet works by reducing platelet aggregation, so that it can inhibit formation of thrombus in the arterial circulation. The aim of this research is determine the level of accuracy of the use of antiplatelet therapy in patients with stroke Inpatient hospital AM Parikesit based Guideline Canadian Cardiovascular Society Antiplatelet Guideline 2011, and PERDOSSI, which includes precise indication, the right patient, the right medication and the right dosage.This study used a non-experimental research design (descriptive). The data collection was done retrospectively from patient medical record. Subjects were patients who meet Inclusion criteria for a primary diagnosis of stroke start at the beginning and end of treatment good receiving antiplatelet therapies or who are not getting treatment antiplatelet during treatment. The data obtained are then processed by descriptive analysis. The results of this research pattern treatment that single antiplatelet used is aspirin (48.6\%), cilostazol (25\%) and clopidogrel $(11.1 \%)$. Antiplatelet combination used is aspirin + clopidogrel $(2.7 \%)$, cilostazol + clopidogrel $(11.1 \%)$ and aspirin + cilostazol (1.3\%). The results of the analysis of the accuracy of the use of
\end{abstract}


antiplatelet therapy is the right indication is $100 \%$, the right of patients is $100 \%$, the right drug is $87.5 \%$, the right dose is $90.2 \%$.

Keywords : antiplatelet, inpatient installation of AM Parikesit hospital, precise treatment, stroke

\section{PENDAHULUAN}

Stroke merupakan salah satu penyakit tidak menular (PTM) yang dapat mengakibatkan kematian dan penyebab utama kecacatan. Dalam pola kematian penderita rawat inap, stroke menduduki urutan pertama. Sedangkan dari seluruh penyebab kematian, stroke menduduki urutan ketiga terbesar setelah penyakit jantung dan kanker. Stroke atau Cerebro Vascular Accident (CVA) adalah kehilangan fungsi otak yang diakibatkan oleh berhentinya suplai darah ke bagian otak, dimana secara mendadak (dalam beberapa detik) atau secara cepat (dalam beberapa jam) timbul gejala dan tanda yang sesuai dengan daerah fokal yang terganggu. Keadaan ini sering merupakan kulminasi penyakit serebrovaskular selama beberapa tahun (Sitorus dkk, 2008).

Sasaran terapi stroke iskemik adalah penyebab yaitu penyakit pembuluh darah besar (emboli pada arteri), emboli pada arteri ke jantung, penyakit pembuluh darah kecil (infark lakuner), penyebab yang jarang terjadi misalnya infark vena, vaskulopati, penggunaan obat, migrain, dan lain-lain (Fagan dan Hess, 2008).

Adapun strategi terapi stroke iskemik meliputi terapi non farmakologi dan terapi farmakologi. Terapi non farmakologi dapat dilakukan dengan modifikasi pola hidup dengan cara menghindari konsumsi alkohol dan rokok, konsumsi makanan sehat dan seimbang, mengurangi berat badan bila kegemukan, sikap hidup rileks dan menghindari stres (Junaidi, 2004). Sedangkan terapi farmakologi stroke iskemik dapat dilakukan dengan reperfusi dan neuroproteksi. Reperfusi yaitu mengembalikan aliran darah ke otak secara adekuat sehingga perfusi meningkat, obat-obat yang dapat diberikan antara lain : thrombolytic agent, inhibitor platelet dan antikoagulan (Junaidi, 2004).

Disamping manfaatnya yang besar dalam pencegahan stroke, obat antiplatelet tetap memiliki risiko yang besar dalam penggunaannya. Sebuah penelitian oleh menunjukkan risiko tinggi terjadinya pendarahan pada penggunaaan antiplatelet ganda (aspirin ditambah clopidogrel). Selain itu dalam guideline NHS Greater Glasgow and Clyde (GGC) tahun 2009 disebutkan beberapa kontraindikasi yang harus diperhatikan dalam penggunaan antiplatelet, seperti penderita PUD (peptic ulcer disease), hemofilia, pendarahan gastrointestinal, ibu menyusui, ataupun bleeding disorder lainnya.

\section{METODE PENELITIAN}

Penelitian ini bersifat retrospektif dan studi ini merupakan penelitian deskriptif yang bersifat non eksperimental. Penelitian dilakukan dengan pengumpulan sampel yaitu pasien stroke yang menjalani rawat inap di RSUD AM Parikesit Tenggarong tahun 2014 yang memenuhi kriteria inklusi. Bahan yang diteliti adalah kartu rekam medik pasien stroke yang menjalani rawat di instalasi RSUD AM Parikesit Tenggarong tahun 2014 dan lembar pengumpulan data yang berisi jenis kelamin, lama rawat inap, umur, kondisi pasien, pemeriksaan fisik, pemeriksaan laboratorium, riwayat penyakit dan pengobatan. Kriteria inklusi penelitian ini adalah pasien rawat inap dengan diagnosis utama stroke mulai dari awal sampai akhir perawatan yang mendapatkan terapi antiplatelet di RSUD AM Parikesit Tenggarong sepanjang tahun 2014. 


\section{HASIL DAN PEMBAHASAN}

\section{Karakteristik Pasien}

\section{a. Distribusi berdasarkan jenis kelamin}

Dari 72 pasien stroke, 38 orang berjenis kelamin laki-laki $(52,8 \%)$ dan 34 orang berjenis kelamin perempuan (47,2\%). Menurut American Heart Association Statistical update (2009), rasio insidensi terkena stroke pada laki-laki lebih tinggi dibanding perempuan pada umur yang muda namun tidak demikian pada umur yang lebih tua.

Salah satu penyebabnya adalah faktor hormonal, pada perempuan premenopause terdapat perlindungan hormon estrogen sehingga terhindar dari penyakit vaskular karena hormon esterogen dapat membantu dalam melebarkan pembuluh darah. (Falcone, 2007). Pada laki-laki terdapat hormon testosteron, dimana hormon ini dapat meningkatkan kadar LDL (Low Density Lipoprotein), apabila kadar LDL tinggi maka dapat meningkatkan kadar kolesterol dalam darah yang merupakan faktor risiko terjadinya penyakit stroke (Bull, 2007).

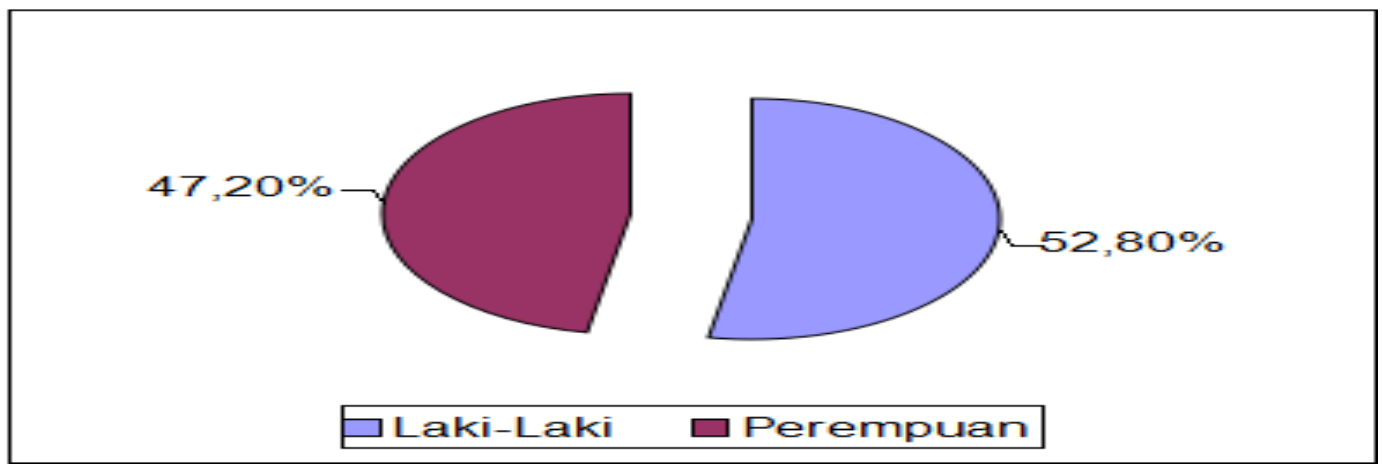

Gambar 1.1 data karakteristik pasien stroke di instalasi rawat inap RSUD A.M Parikesit berdasarkan jenis kelamin.

\section{b. Distribusi pasien berdasarkan usia}

Hasil penelitian didapat bahwa persentase jumlah pasien kelompok umur 30-40 4,2\%, 41-50 tahun $25 \%, 51-60$ tahun $37,5 \%$ dan $\geq 61$ tahun $33,4 \%$. Penelitian ini menunjukkan hasil bahwa prevalensi stroke paling tinggi pada pasien laki-laki terdapat pada kelompok umur 51-60 tahun yaitu 23,6\% dan pada wanita terdapat pada kelompok umur $\geq 61$ yaitu 16,7\%. Pada wanita menopause (usia 40-65 tahun) hormon estrogen menurun tajam dan peluang menderita penyakit jantung semakin meningkat, sehingga faktor risiko terkena stroke meningkat. Hormon estrogen memiliki beberapa fungsi yaitu efeknya pada karakteristik kelamin primer dan sekunder, menaikkan HDL, menurunkan LDL dan menekan Lipoprotein A, selain itu hormon estrogen juga berfungsi sebagai antioksidan (Harsono, 2000).

Data penyebaran penderita stroke berdasarkan umur menunjukkan bahwa makin bertambah usia, risiko terjadinya stroke makin tinggi, dan puncaknya terjadi pada kelompok umur 51-60 tahun namun mengalami sedikit penurunan pada kelompok usia >61 tahun. 


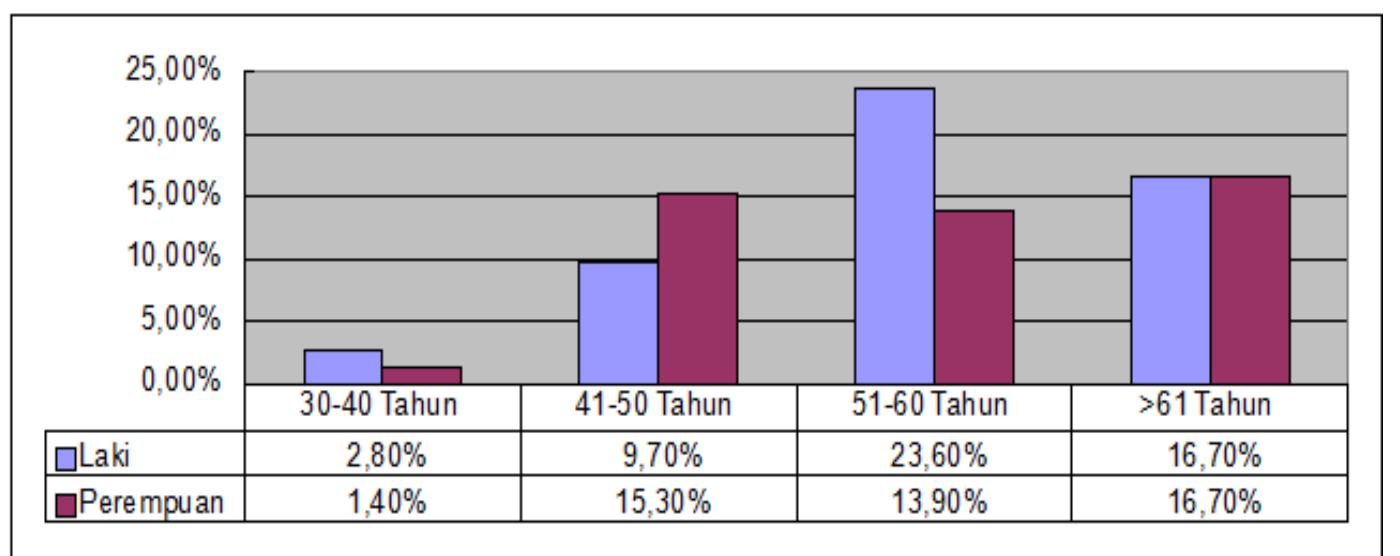

Gambar 1.2 data karakteristik pasien stroke di instalasi rawat inap RSUD A.M Parikesit berdasarkan usia.

\section{c. Distribusi pasien berdasarkan pekerjaan}

Dari tingkat pekerjaan dapat dijabarkan bahwa persentase tertinggi pasien penderita stroke sebagian besar adalah ibu rumah tangga (IRT)/pensiunan, pada kelompok ini dapat dikategorikan dalam kelompok masyarakat yang tidak bekerja. Persentase pasien yg tidak berkerja 41,6\%.

Status sosial berhubungan dengan peningkatan kematian akibat stroke. Hal ini disebabkan karena tingginya kejadian stroke pada penduduk yang tidak berkerja dan berpenghasilan rendah, karena tingginya stres pada penderita tersebut, diet yang rendah, maupun nutrisi dan kesehatan yang rendah (Junaidi, 2004).

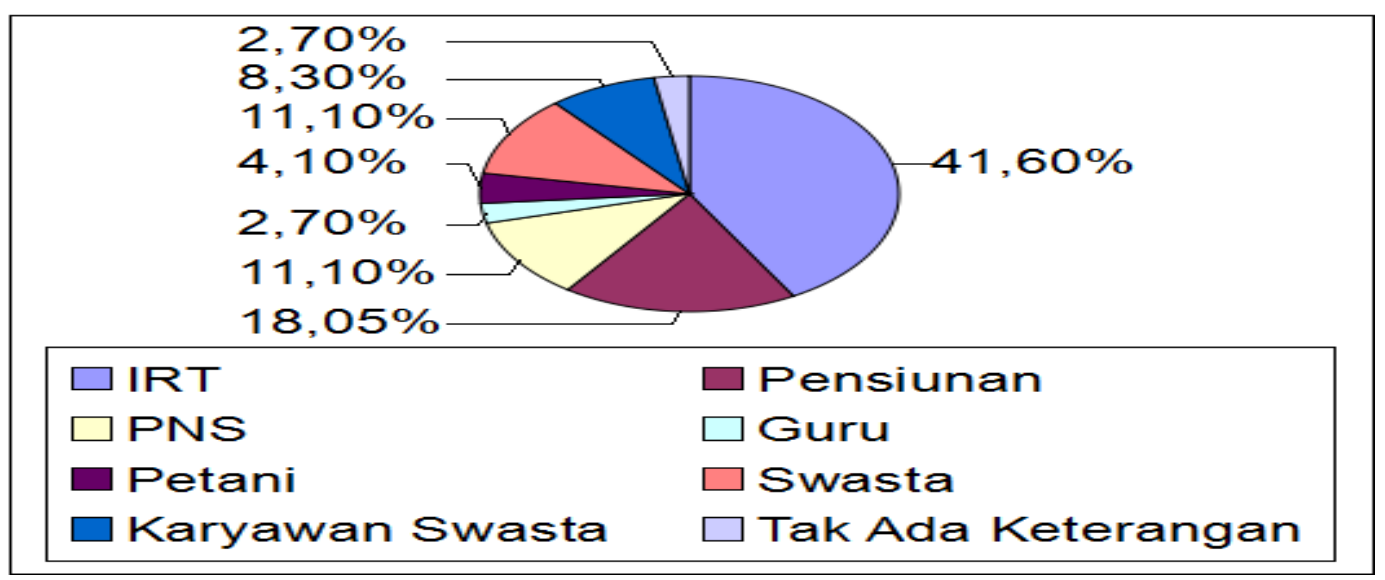

Gambar 1.3 data karakteristik pasien stroke di instalasi rawat inap RSUD A.M Parikesit berdasarkan pekerjaan.

\section{d. Distribusi pasien berdasarkan lama rawat inap}

Secara keseluruhaan lama rawat penderita stroke paling lama yaitu dirawat selama kurang dari satu minggu. Lamanya pasien stroke menjalani rawat inap kemungkinan disebabkan oleh lamanya pemulihan kondisi pasca stroke, selain itu pasien juga menjalani fisioterapi selama beberapa waktu. 


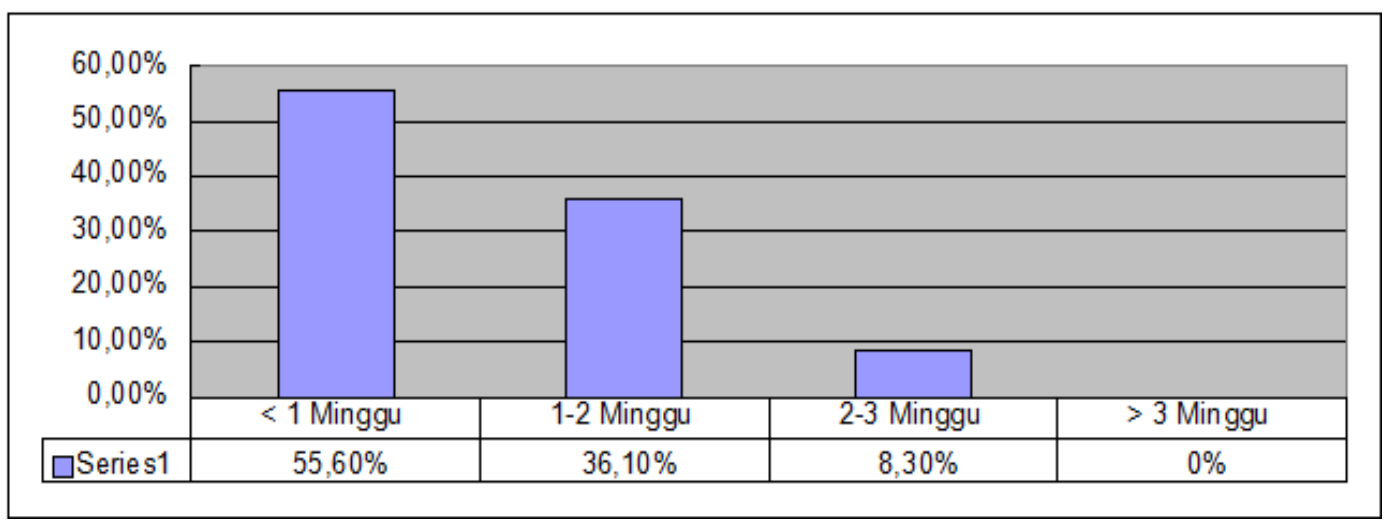

Gambar 1.4 data karakteristik pasien stroke di instalasi rawat inap RSUD A.M Parikesit berdasarkan lama rawat inap.

\section{e. Distribusi pasien berdasarkan status keluar dari rumah sakit}

Status keluar adalah kondisi saat keluar dari rumah sakit. Penulisan status keluar di RSUD AM Parikesit dibedakan menjadi 5, yaitu sembuh, membaik, belum sembuh, atas permintaan sendiri (APS) berhenti rawat inap dan meninggal. Status membaik adalah pasien diizinkan meninggalkan bangsal karena kondisi pasien yang telah membaik dan stabil sehingga dapat dilakukan terapi lanjutan atau rawat jalan. Status APS diberikan jika pasien dan keluarga meminta pulang paksa meskipun kondisi pasien belum membaik.

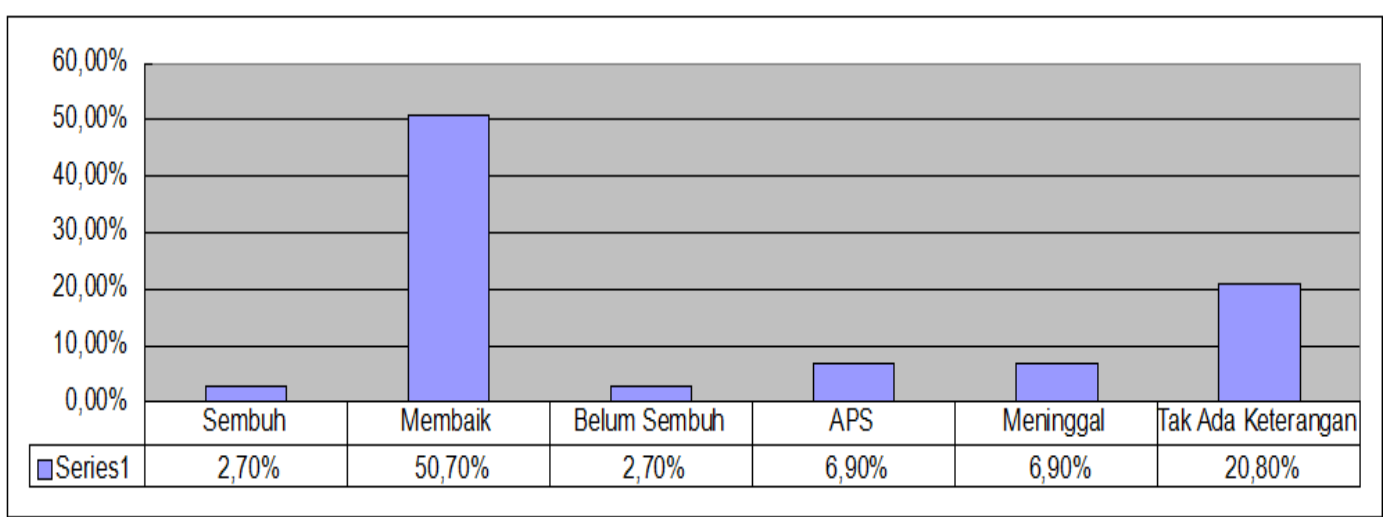

Gambar 1.5 data karakteristik pasien stroke di instalasi rawat inap RSUD A.M Parikesit berdasarkan status keluar.

Gambar di atas menunjukkan persentase terbanyak adalah kondisi pasien yang membaik yaitu 50,7\%. Namun terdapat 15 kasus (20,8\%) yang tidak diketahui status keluarnya karena tidak tercantum di rekam medik.

\section{f. Distribusi pasien berdasarkan faktor risiko penyakit}

Pada penelitian ini terdapat dua jenis faktor risiko terbanyak yaitu hipertensi. Secara umum telah diketahui bahwa hipertensi berkaitan dengan peningkatan risiko terjadinya stroke dan sebaliknya hipertensi yang terkontrol dengan baik akan menurunkan risiko tersebut. Hipertensi mendorong timbulnya stroke lewat diperberatnya atherosklerosis pada arkus aorta maupun arteri servikoserebral (Sitorus dkk, 2008). 
Tabel 1 Distribusi pasien berdasarkan faktor risiko penyakit di instalasi rawat inap RSUD A.M Parikesit

\begin{tabular}{c|c|c}
\hline Jenis Penyakit & Jumlah kasus & Persentase \\
\hline Hipertensi & 15 & $20,8 \%$ \\
Diabetes & 8 & $11,1 \%$ \\
Transient Ischemic Attacks (TIA) & 2 & $2,7 \%$ \\
Dislipidemia & 1 & $1,3 \%$ \\
Atrial fibrillation (AF) & 1 & $1,3 \%$ \\
\hline
\end{tabular}

\section{Gambaran Pola Penggunaan Antiplatelet di Instalasi Rawat Inap RSUD AM Parikesit Tenggarong 2014}

Penggunaan antiplatelet dalam pengobatan stroke di Instalasi rawat inap RSUD AM Parikesit Tenggarong Tahun 2014, terdiri dari tiga kelas yaitu kelas Cyclooxygenase inhibit or (Aspirin), Adenosine diphosphate receptor inhibitor (Clopidogrel), dan Phosphodiesterase inhibitors (Cilostazol).

Tabel 2 Gambaran Pola Penggunaan Antiplatelet di Instalasi Rawat Inap RSUD AM Parikesit.

\begin{tabular}{lccc}
\hline & Nama Obat & Jumlah Kasus & Persentase \\
\hline Tunggal & & 35 & $48,6 \%$ \\
& Aspirin & 18 & $25 \%$ \\
\multicolumn{1}{c}{ Total } & Cilostazol & 8 & $11,1 \%$ \\
Kombinasi & Clopidogrel & 61 & $84,7 \%$ \\
& & & \\
& Aspirin + Clopidogrel & 2 & $2,7 \%$ \\
& Aspirin + Cilostazol & 1 & $1,3 \%$ \\
Total & Cilostazol + Clopidogrel & 8 & $11,1 \%$ \\
Total Antiplatelet Tunggal dan Kombinasi & 11 & $15,2 \%$ \\
\hline
\end{tabular}

Berdasarkan data yang diperoleh maka penggunaan terbanyak obat antiplatelet adalah penggunaan obat Aspirin yaitu 35 kasus atau 48,6\%. Sebuah penelitian yang dilakukan dengan antitrombotik, memberikan bukti adanya manfaat obat antiplatelet terutama aspirin dalam mencegah kejadian kardiovaskular pasien berisiko tinggi. Namun terdapat risiko efek samping yang serius yaitu terjadi perdarahan. Namun pada pasien dengan risiko kejadian oklusi vaskular yang tinggi, manfaat terapi antiplatelet jauh lebih besar daripada risiko pendarahannya kecuali jika risiko absolut perdarahan ekstrakranial tinggi. Sebuah penelitian mengidentifikasi bahwa pasien yang memakai dosis aspirin $<100 \mathrm{mg}$ tiga kali lebih rendah mengalami komplikasi perdarahan dibandingkan dengan pasien yang memakai dosis 100-200mg atau >200mg (Anonim, 2005).

\section{KESIMPULAN}

Karakteristik Pasien Stroke di Instalasi Rawat Inap RSUD AM Parikesit 38 orang berjenis kelamin laki-laki $(52,8 \%)$ dan 34 orang berjenis kelamin perempuan $(47,2 \%)$, persentase tertinggi pasien kelompok umur pada 51-60 tahun (37,5\%), persentase tertinggi pasien penderita stroke sebagai ibu rumah tangga (IRT)/pensiunan $(41,6 \%)$, distribusi pasien berdasarkan lama rawat inap 
tertinggi yaitu dirawat selama kurang dari satu minggu $(55,60 \%$,) distribusi pasien berdasarkan status keluar dari rumah sakit tertinggi yaitu membaik $(50,7 \%)$, distribusi pasien berdasarkan faktor risiko penyakit Hipertensi 15 kasus (20,8 \%), Diabetes 8 kasus (11,1\%), Transient Ischemic Attacks (TIA) 2 kasus $(2,7 \%)$, Dislipidemia 1 kasus $(1,3 \%)$,Atrial fibrillation (AF) 1 kasus (1,3\%). Pola pengobatan penyakit stroke di Instalasi Rawat Inap RSUD AM Parikesit Tenggarong yaitu antiplatelet tunggal yang digunakan adalah Aspirin (48,6\%), cilostazol $(25 \%)$ dan clopidogrel $(11,1 \%)$. Antiplatelet kombinasi yang digunakan adalah aspirin + clopidogrel $(2,7 \%)$, cilostazol + clopidogrel $(11,1 \%)$ dan aspirin + cilostazol $(1,3 \%)$.

\section{SARAN}

Diperlukan suatu studi prospektif untuk menganalisis ketepatan terapi antiplatelet pada pasien stroke mengingat kontraindikasi dan efek samping pada terapi menggunakan antiplatelet dinilai cukup berat dan perlu dibuat Standar Pelayanan Medik (SPM) stroke yang lebih lengkap dan mengacu pada guidelines terbaru baik dari luar negeri ataupun dari dalam negeri, serta bagi pihak rumah sakit, kelengkapan data rekam medik dan kejelasan tulisan akan membantu bagi penelitian selanjutnya.

\section{DAFTAR PUSTAKA}

Anonim, 2005, Prescribing antiplatelet drugs in primary care, National Prescribing Centre, National Health Service.

Bull, Eleanor., 2007, Simple Guide:Cholesterol, Penerbit Erlangga, Jakarta cit Jerry, 2011 Drug Related Problems Pada Pasien Rawat Inap Stroke Iskemik di Ruang Perawatan Neurologi RSSN Bukittinggi, Tesis, Magister Farmasi Universitas Andalas, Padang.

Fagan, S. C. \& Hess, D.C., dalam Dipiro, J.T., Talbert, R.I., Yee, G.C., Matzke, G.R., Wells, B.G., Posey, L.M. 2008. Pharmacotherapy A Pathophysiologic Approach, Mc Graw Hill, Medical Publishing Divission, New York.

Harsono, 2000, Kapita Selekta Neurologi ED 2, 81-101, Gadjah Mada University Press, Yogyakarta.

Jones, D.L., Adams, R., Carnethon, M., Simone, G.D., Ferguson, T.B., Flegal, K., Ford, E., Furie, K., Go, A., Greenlund, K., Haase, N., Hailpern, S., Ho, M., Howard, V., Kissela, B., Kittner, S., Lackland, D., Lisabeth, L., Marelli, A., McDermott, M., Meigs, J., Mozaffarian, D., Nichol, G., O’Donnell, C., Roger, V., Rosamond, W., Sacco, R., Sorlie, P., Stafford, R., Steinberger, J., Thom, T., Smoller, S.W., Wong, N., Rosset, J.W., Hong, Y., 2009, Heart Disease and Stroke Statistics, Journal Of The American Heart Association, American Heart Association Statistics Committee and Stroke Statistics Subcommittee.

Junaidi, I. 2004. Panduan Praktis Pencegahan dan Pengobatan Stroke. PT Bhuana Ilmu Populer Kelompok Gramedia. Jakarta.

Sitorus, R.J., Hadisaputro, S., Kustiowati, E. 2008. Faktor-Faktor Risiko Yang Mempengaruhi Kejadian Stroke Pada Usia Muda Kurang Dari 40 Tahun (Studi Kasus Di Rumah Sakit Di Kota Semarang). Laporan Penelitian. Universitas Diponegoro. Semarang. 